\title{
ANALISIS KEMAMPUAN INTELEKTUAL MENYUSUN LAPORAN KEUANGAN TERHADAP DAYA SAING BAGI UMKM DI KOTA BATAM DALAM MENGHADAPI MASYARAKAT EKONOMI ASEAN
}

\author{
Hardi Bahar \\ Fakultas Bisnis, Universitas Universal \\ email: hardibahar86@gmail.com
}

\begin{abstract}
SMES participated in economic growth and infrastructure development in the country. The growth and development is not detached from the players of the economic actors who have micro, small, and medium enterprises. Some of the activities of SMES in conducting their business during the free market are certainly utilizing the ability to perform various innovations in terms of finance in order to excel in winning the competition. This research aims to determine how, and how much relationship, the influence of the factors chosen by the authors as a variable of research, namely the intellectual ability to the competitiveness of SMES in Batam City. The population in the research to be conducted is SMES in Batam city. While the selection of samples used in this study is purposive sampling. The data collection techniques in this study used are interviews and questionnaires. The method used in data analysis is the descriptive data analysis and the data analyzed using SmartPls analysis in testing the data of the intellectual ability to compile financial report and competitiveness for SMES in Batam City. Based on the results of the analysis of the intellectual ability to compile financial statements on the competitiveness known intellectual ability to compose financial statements that have been implemented by the business actors are still weak overall reach $8 \%$ and Intellectual ability to compose financial statements does not affect the competitiveness.
\end{abstract}

Keywords: Intellectual ability to compile financial statements, Competitiveness

\begin{abstract}
ABSTRAK
UMKM ikut serta dalam pertumbuhan ekonomi dan perkembangan infrastruktur pada negara tersebut. Pertumbuhan dan perkembangan tersebut tidak terlepas dari pemain para pelaku ekonomi tersebut yang diantaranya memiliki usaha mikro, kecil, dan menengah. Sebagian aktivitas UMKM dalam menjalankan usahanya pada saat pasar bebas tentu para pelaku usaha memanfaatkan kemampuan untuk melakukan berbagai inovasi dari segi keuangan agar unggul dalam memenangkan persaingan. Penelitian ini bertujuan untuk mengetahui bagaimana, dan seberapa besar hubungan, pengaruh faktor-faktor yang dipilih penulis sebagai variabel penelitian yaitu kemampuan intelektual terhadap daya saing UMKM di Kota Batam. Populasi dalam penelitian yang akan dijalankan adalah UMKM di Kota Batam. Sedangkan pemilihan sampel yang digunakan dalam penelitian ini adalah purposive sampling. Teknik pengumpulan data dalam penelitian ini yang digunakan adalah wawancara dan kuesioner/angket. Metode yang digunakan dalam analisis data yaitu analsis data deskriptif dan data yang dianalisis memakai analisis SmartPls dalam menguji data dari kemampuan intelektual menyusun laporan keuangan dan daya saing bagi UMKM di Kota Batam. Berdasarkan hasil dari analisis kemampuan intelektual menyusun laporan Keuangan terhadap daya saing diketahui kemampuan intelektual menyusun laporan keuangan yang telah diimplementasikan oleh pelaku usaha masih lemah secara keseluruhan mencapai $8 \%$ dan peubah kemampuan intelektual menyusun laporan Keuangan tidak berpengaruh secara nyata terhadap daya saing.
\end{abstract}

Kata Kunci: Kemampuan intelektual menyusun laporan keuangan, Daya Saing ${ }^{*}$

*Corresponding Author Email: hardibahar86@gmail.com 


\section{PENDAHULAN}

UMKM selalu ikut serta dalam pertumbuhan ekonomi dan perkembangan

infrastruktur pada tiap negara. Pertumbuhan dan perkembangan tersebut tidak terlepas dari pemain para pelaku ekonomi yang diantaranya memiliki usaha mikro, kecil, dan Menengah yang ada masing-masing di negara tersebut. Para pelaku usaha dalam menjalankan peran dari usahanya tersebut dapat kita ketahui bahwasanya pelaku ekonomi terutama UMKM dalam mengembangkan perekonomian nasional ditetapkan oleh Undang-Undang RI nomor 20 tahun 2008 (Undang-Undang No. 20, 2008) tentang usaha kecil dan ditambah lagi dari peraturan pemerintah RI nomor 32 tahun 1998 tentang pembinaan dan pengembangan usaha kecil. Berdasarkan landasan tersebut, UMKM dihadapi berbagai permasalahan dengan adanya era pasar bebas dan persaingan dalam menjalankan usahanya yang semakin sangat ketat, terlebih lagi MEA (Masyarakat Ekonomi Asean) sudah diberlakukan. Kondisi MEA yang sudah diberlakukan, para pemilik usaha perlu berupaya untuk terus bertahan dan lebih unggul dalam persaingan tersebut tentu UMKM memiliki berbagai macam kompetensi yang dapat mempengaruhi kinerja dalam menjalankan usahanya. Perkembangan UMKM di Kota Batam tiap tahun sangat berkembang dengan pesat. Adapun pada tahun 2019 jumlah UMKM di Kota Batam yaitu sebanyak 81.486 dari usaha yang mikro, kecil hingga Menengah.

Sebagian aktivitas UMKM dalam menjalankan usahanya pada saat pasar bebas tentu para pelaku usaha memanfaatkan kemampuan untuk melakukan berbagai inovasi dari segi keuangan agar unggul dalam memenangkan persaingan terutama kemampuan intelektual dalam hal menyusun dan memahami berbagai komponen laporan Keuangan yang dimiliki para pelaku UMKM . Pada era ekonomi batam sedang buruk, sejumlah usaha kecil dan menengah masih bisa sanggup bertahan dari goncangan krisis tetapi terdapat para pelaku usaha mendapat goncangan penurunan dari omset dan penjualan (Putut, 2019). Serta setelah diterapkannya ASEAN-CHINA Free Trade Association (ACFTA) tahun 2010 dan Masyarakat Ekonomi ASEAN (MEA) di tahun 2016 membuat persaingan di Indonesia terutama industri logam maupun elektronik semakin ketat, hal ini sangat mudahnya produk dari luar negeri masuk ke dalam pasar yang ada di Kota Batam dan mendapatkan kekuatan tawar menawar dari pemasok maupun pembeli baik dari jenis produk yang ditawarkan (Dwi, Kusuma \& Rahardjo, Toto, 2017). Dengan ini tentu UMKM memiliki hambatanhambatan dalam mengindikasikan bahwa masyarakat terkesan kurang memiliki kompetensi atau kemampuan intelektual dan persaingan pada sektor informal melalui pengembangan UMKM. Dengan demikian, persoalan-persoalan UMKM secara umum yang telah dijelaskan yaitu persoalan manajemen dalam kompetensi atau kemampuan keuangan dan pemahaman persaingan dalam mengembangkan UMKM. Oleh karena itu penelitian ini bertujuan untuk mengetahui bagaimana, dan seberapa besar hubungan, pengaruh faktor-faktor yang dipilih penulis sebagai variabel penelitian yaitu kompetensi dalam kemampuan intelektual dalam memahami dan menyusun berbagai komponen laporan keuangan terhadap Daya saing UMKM di Kota Batam. Dengan alasan tersebut diatas maka peneliti mengambil judul "Analisis Kemampuan Intelektual Menyusun Laporan Keuangan Keuangan Terhadap Daya Saing Bagi UMKM di Kota Batam Dalam Menghadapi Pasar Bebas". 


\section{KAJIAN LITERATUR}

Kajian literatur menjelaskan teori dan penelitian terdahulu yang berkaitan dengan topik penelitian yang menjadi landasan logis dalam mengembangkan hipotesis penelitian termasuk kerangka konsep penelitian.. [Times New Roman, 12, normal], spasi 1.

\section{Kompetensi atau Kemampuan}

Beberapa pandangan yang berkaitan dengan kompetensi. Menurut Wibowo kompetensi adalah sebagai suatu kemampuan untuk melaksanakan suatu tugas yang dilandasi atas keterampilan dan pengetahuan yang didukung oleh sikap kerja yang dituntut oleh pekerjaan. Sementara Spencer berpendapat bahwa kompetensi merupakan kemampuan yang dimiliki individu dari aspek pengetahuan, keterampilan dan aspek sikap (Dhamayantie \& Fauzan, 2017).

Berdasarkan pandangan dari teori yang sudah dijelaskan dapat dikatakan bahwa kompetensi ialah karakteristik dari individu yang dimiliki atas pengalaman yang didukung atas kemampuan untuk melaksanakan suatu pekerjaan atas aspek pengetahuan, keterampilan dan aspek sikap.

Untuk mengukur kompetensi, berikut beberapa indikator dari kompetensi. Menurut Hidayat dan Suhayati (Hidayat \& Suhayati, 2017) indikator kompetensi sebagai berikut:

1.Pengetahuan

2.Kemampuan (Skill)

3.Pengalaman

4.Pelatihan

Sedangkan menurut Gursoy dan Nancy (Gursoy \& Swanger, 2007) kompetensi wirausaha terbagi menjadi tujuh, antara lain:

1.Kompetensi Penjualan

2.Kompetensi Layanan

3.Kompetensi marketing

4.Kompetensi keuangan,

5.Kompetensi R\&D dan Distribusi,

6.Kompetensi dalam Teknologi Informasi,
7.Kompetensi dalam manajemen sumber daya manusia.

Berdasarkan penjelasan tersebut dapat disimpulkan bahwa dalam mengukur kompetensi instrumen item yang akan digunakan dalam penelitian ini meliputi:

1. Pengetahuan

2. Kemampuan (Skill)

3. Pengalaman

4. Pelatihan

5. Kompetensi Penjualan

6. Kompetensi Layanan

7. Kompetensi marketing

8. Kompetensi keuangan,

9. Kompetensi R\&D dan Distribusi,

10. Kompetensi dalam Teknologi

Informasi,

11. Kompetensi dalam manajemen sumber daya manusia,

(Adopsi (Gursoy \& Swanger, 2007) dan

(Hidayat \& Suhayati, 2017) )

\section{Kompetensi atau Kemampuan Keuangan}

Ada beberapa hal yang dapat diketahui pada kemampuan Keuangan atau kompetensi Keuangan dari beberapa teori yaitu: Menurut (Gursoy \& Swanger, 2007) kompetensi Keuangan dilihat dari Manajemen Aset, Investasi dan analisis risiko, Komponen laporan keuangan. Sedangkan menurut (Nurlaela, 2015) kemampuan menyusun laporan Keuangan yang dimiliki pelaku UMKM dapat dilihat dalam hal kemampuan intelektual yaitu ingatan, kemahiran berhitung atau mencatat, kecepatan konseptual, pemahaman verbal, penalaran induktif dan visualisasi ruang. Berdasarkan dari teori diatas maka kompetensi Keuangan dalam menjalankan usahanya yang dilakukan oleh para pelaku UMKM dapat dilihat dari pengelolaan asset yang ada pada UMKM, Investasi yang dimiliki dan dapat di analisis resiko dari investasinya bagi UMKM dan Kemampuan atas menguasai komponen-komponen laporan Keuangan yang dimiliki bagi UMKM. 


\section{Daya Saing}

Beberapa pandangan berkaitan dengan persaingan. Menurut Kasmir (Martini, Tini; Thamrin, Rammelsbergi, 2016) Pesaing adalah menghasilkan atau menjual barang atau jasa yang sama produk yang kita tawarkan. Sedangkan Esterhuizen et.al (Zulgani, Syaparuddin, \& Parmadi, 2014) memandang defenisi daya saing diartikan sebagai kemampuan suatu sektor, industri untuk bersaing dengan sukses untuk mencapai pertumbuhan yang berlanjut di dalam lingkungan global selama biaya penyeimbangnya lebih rendah dari penerimaan sumberdaya yang diberikan. Selanjutnya Krugman dan Obstfeld (Zulgani et al., 2014) daya saing merupakan suatu komoditas sering diukur dengan menggunakan pendekatan keunggulan komparatif dan kompetitif.

Berdasarkan pandangan dari teori yang sudah dikemukakan bahwa Daya saing merupakan usaha-usaha yang dilakukan perusahaan, sektor atau komoditas yang kegiatannya menyediakan produk, jasa, dan harga yang siap untuk bersaing dengan sukses untuk mencapai perkembangan yang berkelanjutan.

Untuk mengukur daya saing usaha atau industri perlu diperhatikan. Menurut Han et.al (Munizu, Surachman, Salim, \& Solimum, 2012) indikator dalam daya saing yang ada di perusahaan dapat dilihat dari Kualitas, biaya, pengiriman dan fleksibilitas Menurut ramlawati dan lakhal (Munizu et al., 2012) indikator pada daya saing ialah price/cost, delivery dependability, product innovation, dan time to market. Sedangkan menurut Hit et.al (Handriani, 2011) indikator pada daya saing tersebut berupa tingkat sampai sejauh mana suatu perusahaan dapat memenuhi permintaan pasar, baik domestik maupun internasional, dalam memproduksi barang dan jasa, dengan tetap mempertahankan atau meningkatkan pendapatan perusahaan dan karyawannya

Berdasarkan penjelasan tersebut dapat disimpulkan bahwa daya saing memperhatikan dan mempertimbangkan faktor dari inovasi produk, harga atau biaya, dan permintaan pasar lokal dan internasional.

\section{Model Penelitian}

Adapun model awal penelitian ini yaitu

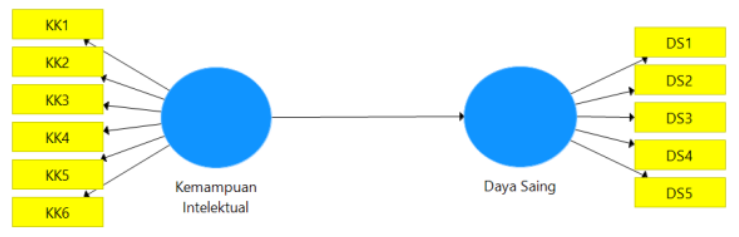

\section{Hipotesis Penelitian}

Hipotensi dalam penelitian yang akan dijalankan sebagai berikut:

H1 : Ada pengaruh kompetensi keuangan UMKM dengan daya saing

\section{METODE PENELITIAN}

\section{Desain Penelitian, lokasi penelitian, populasi dan sampel}

Adapun desain penelitian ini adalah sebagai berikut awal mula kegiatan ditentukan permasalahan yang diteliti, kedua setelah ditentukan maka data dikumpulkan melalui teknik pengumpulan menggunakan angket (kuesioner), ketiga selanjutnya dilakukan analisis data menggunakan Aplikasi Smart PLS, setelah itu didapatkan hasil dan pembahasan dan selanjutnya disimpulkan hasil penelitian tersebut.

Penelitian yang akan dijalankan ini berlokasi di Kota Batam Provinsi Kepulauan Riau. Pada populasi dalam penelitian yang akan dijalankan adalah UMKM di Kota Batam. Sedangkan pemilihan sampel yang digunakan dalam penelitian ini adalah purposive sampling Purposive sampling yang memenuhi kriteria sebagai berikut: UMKM aktif di Kota Batam dan pelaku bisnis bersedia menjadi subyek penelitian.

Total subyek yang direkrut dalam penelitian ini sebanyak 104 pelaku UMKM. 


\section{Variabel Penelitian}

Variabel dalam penelitian terdiri Kemampuan Intelektual (X1) sebagai variabel bebas (X) dan Daya Saing sebagai variabel terikat (Y). Sedangkan indikator yang digunakan dalam penelitian yang akan dijalankan adalah sebagai berikut:

Indikator Kemampuan Intelektual menurut Robbin dalam (Nurlaela, 2015) terdiri dari:

1. Ingatan, Pelaku usaha mampu mengumpulkan bukti transaksi

2. Kemahiran berhitung atau mencatat, pelaku usaha mampu mencatat dan menghitung segala transaksi

3. Kecepatan konseptual, pelaku usaha mampu mengelompokkan transaksi ke dalam buku catatan Keuangan

4. Pemahaman verbal, Pelaku usaha mampu membaca isi laporan Keuangan

5. Penalaran induktif dan deduktif, pelaku usaha mampu menganalisis isi laporan Keuangan

6. Visualisasi ruang, pelaku usaha mampu mengambil keputusan dari hasil analisis tersebut (Nurlaela, 2015)

Sedangkan Indikator Daya Saing terdiri dari 4 item yaitu:

1. Price/Cost

2. Quality,

3. Delivery Dependability,

4. Produk Innovation dan

5. Time to market (Munizu et al., 2012)

\section{Teknik Pengumpulan Data}

Teknik pengumpulan data dalam penelitian ini yang digunakan adalah wawancara dan kuesioner/angket. (Sugiyono, 2017)

\section{Analisis Data}

\section{Analisis deskriptif}

Pada hakikatnya, metode analisis deskriptif dalam penelitian merupakan proses transformasi data penyelidikan dalam bentuk tabel, sehingga mudah dipahami dan dijelaskan. Statistik deskriptif adalah statistik yang memberikan gambaran atau deskripsi suatu data yang ketahui berdasarkan skor rata-rata, standar deviasi, varian, maksimum, minimum dan kurtosis (Ghozali, 2008). Metode ini pada umumnya digunakan untuk menjelaskan gambaran tentang objek yang diteliti seperti karakteristik responden yang seperti, jenis kelamin, status perkawinan, masa kerja, dan tingkat pendidikan. Penyebaran data dianggap baik jika nilai standar deviasi lebih kecil dari $30 \%$ daripada nilai rata-rata (Singgih, 2011).

Skor rata-rata yang digunakan dalam analisis kajian deskriptif adalah berdasarkan skala likert dengan kriteria analisi deskriptif sebagai berikut:

\section{Tabel 1. Kriteria Analisis Deskriptif}

\begin{tabular}{|c|c|}
\hline $\begin{array}{c}\text { Nilai Skor Rata- } \\
\text { rata }\end{array}$ & Penafsiran \\
\hline $1.00-1.79$ & Sangat Tidak Baik \\
\hline $1.80-2.59$ & Tidak Baik \\
\hline $2.60-3.39$ & Cukup \\
\hline $3.40-4.19$ & Baik \\
\hline $4.20-5.00$ & Sangat Baik \\
\hline
\end{tabular}

\section{Analisis SEM PLS}

Partial Least Square (PLS) adalah salah satu teknik Structural Equation Modelling (SEM) yang mampu menganalisis variabel laten, variabel indikator dan kesalahan pengukuran secara langsung. PLS dikembangkan sebagai alternatif apabila teori yang digunakan lemah atau indikator yang tersedia tidak memenuhi model pengukuran reflektif. PLS merupakan metode analisis yang powerfull kerana dapat diterapkan pada semua skala data, tidak banyak membutuhkan asumsi, ukuran sampel tidak besar. Selain dapat digunakan untuk konfirmasi teori, $P L S$ juga dapat digunakan untuk membangun hubungan yang belum ada landasan teorinya atau pengujian proposisi (Singgih, 2011). Ujian Model dilakukan melalui outer model dan inner model. Untuk lebih jelasnya berikut kriteria penilaian.

Jika suatu item secara konsisten diletakkan dalam suatu kategori tertentu, maka dapat dianggap menunjukkan validitas konvergent (convergent validity) 
dengan konstruk yang berhubungan dan validitas diskriminant (discriminant validity) dengan konstruk lainnya (Singgih, 2011) (Singgih, 2017) (Ghozali, 2008) (Ghozali, 2016).

Tabel 2. Batasan Skor Cronbach's Alpha

\begin{tabular}{|c|c|}
\hline Skor & Kebolehpercayaan \\
\hline$<0.50$ & Rendah \\
\hline $0.50-0.60$ & Cukup \\
\hline $0.70-0.80$ & Tinggi \\
\hline
\end{tabular}

\section{HASIL DAN PEMBAHASAN}

\section{Karakteristik Responden}

Berdasarkan hasil penyebaran kuesioner pada responden di lapangan, Kuesioner yang diterima bagi pelaku UMKM di Kota Batam terdapat 67\% lakilaki dan 33\% Perempuan. Kuesioner yang dibagikan kepada para pelaku usaha menggunakan metode purposive sampling.

Pada analisis ini dapat diketahui dengan pendekatan PLS yang digunakan melihat pengaruh langsung antara Kemampuan Intelektual Terhadap Daya Saing. Pada Evaluasi PLS ini dilakukan dengan menilai beberapa model dalam penelitian ini yaitu model pengukuran (Outer Model) dan model struktural (Inner Model).

\section{Model Pengukuran (Outer Model)}

Pada outer model ini digunakan dalam menilai validitas dan reliabiltas model. Penelitian yang dilakukan mengenai Kemampuan Intelektual Menyusun Laporan Keuangan Pada Daya Saing menggunakan indikator reflektif sehingga outer model dievaluasi melalui validitas convergent dan discriminant dari pembentuk konstruk laten dan composite reliability digunakan untuk blok indikator (Ghozali, 2015). Dalam mengevaluasi validitas convergent diukur dengan menggunakan loading factor dan nilai Average Variance Extracted (AVE). Nilai loading factor jika dikatakan baik nilai Validity ketika nilainya lebih dari 0,7 yang menunjukkan korelasi skor indikator dengan konstruknya pada penelitian yang bersifat confirmatory sedangkan nilai loading factor nya antara 0,6-0,7 pada penelitian yang bersifat exploratory. Serta pada Nilai AVE menganjurkan nilai di dapatkan lebih besar dari $0,5 \%$ yang mempunyai makna bahwasanya $50 \%$ atau lebih varians dari indikatornya dapat dijelaskan.

Menilai dari Evaluasi validitas diskriminan dengan cara membandingkan akar kuadrat dari average variance extracted pada setiap konstruk dengan konstruk lainnya dari model tersebut. Model mempunyai validitas diskriminan yang cukup apabila akar AVE yang didapatkan setiap konstruk lebih besar dari korelasi konstruk lainnya. Sedangkan pada uji reliabilitas dikatakan baik dilihat dengan cara menilai composte reliability diatas 0,7 untuk penelitian confirmatory dan nilai antara 0,6-0,7 untuk penelitian exploratory.

Berikut data yang sudah diolah berdasarkan model akhir SEM PLS dalam mengukur loading factor, Composite Reliability dan Average Variance Extracted (AVE) sebagai berikut:

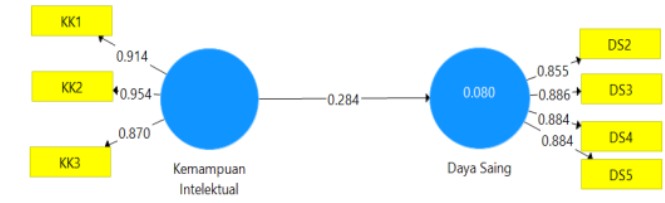

Gambar 1. Model Akhir SEM PLS Sumber: SmartPIS 3, 2019

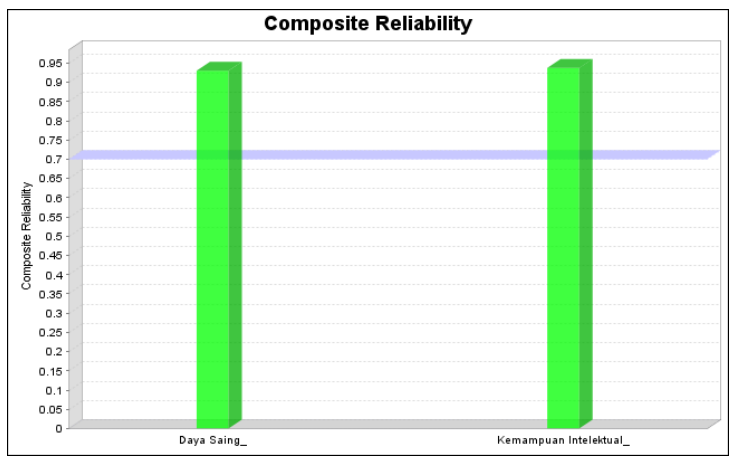

Gambar 2. Composite Reliability

Sumber: SmartPIS 3, 2019 


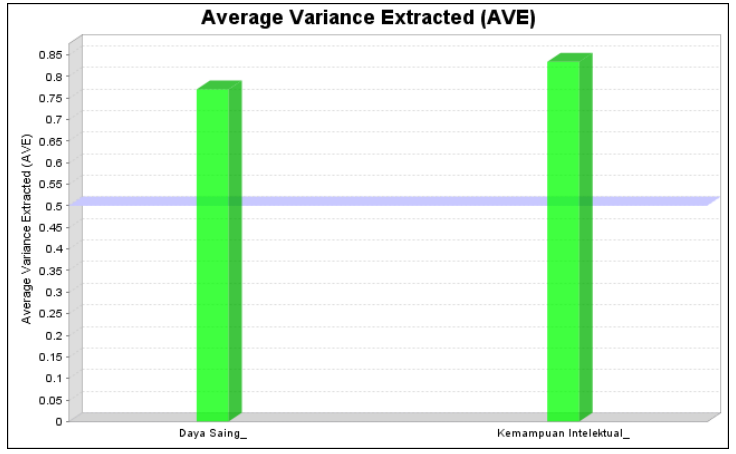

Gambar 3. Average Variance Extracted (AVE) Sumber: SmartP1S 3, 2019

Berdasarkan hasil dari pengolahan data yang telah dilakukan dengan menggunakan aplikasi software SMART PLS3 dapat kita perhatikan dari gambar di atas baik dari model akhir SEM PLS, composite reliability dan average Variance Extracted dengan kriteria penilaian, standar, hasil penelitian dan kesimpulan yang didapatkan sebagai berikut:

Tabel 3. Hasil Penelitian Dari Penilaian Kriteria Dan Standar Nilai Mode Reflektif

\begin{tabular}{|c|c|c|c|c|}
\hline No & Kriteria & Standar & $\begin{array}{c}\text { Hasil } \\
\text { Penelitian }\end{array}$ & Kesimpulan \\
\hline 1 & $\begin{array}{l}\text { Loading } \\
\text { Factor }\end{array}$ & $\geq 0,6$ & $\begin{array}{l}\text { KK1 } \\
0,914 \\
\text { KK2 } \\
0,954 \\
\text { KK3 } \\
0,870 \\
\text { DS2 } \\
0,855 \\
\text { DS3 } \\
0,886 \\
\text { DS4 } \\
0,884 \\
\text { DS5 } \\
0,884\end{array}=$ & Memenuhi \\
\hline 2 & $\begin{array}{l}\text { Composite } \\
\text { Reliability }\end{array}$ & $\geq 0,6$ & $\begin{array}{l}\text { KK } \\
0,938 \\
\text { DY } \\
0,930\end{array}$ & Memenuhi \\
\hline 3 & $\begin{array}{l}\text { Average } \\
\text { Variance } \\
\text { Extracted } \\
(\text { AVE) }\end{array}$ & $\geq 0,5$ & $\begin{array}{l}\text { KK } \\
0,834 \\
\mathrm{DY} \\
0,770\end{array}$ & Memenuhi \\
\hline 4 & $\begin{array}{l}\text { Akar } \\
\text { Kuadrat } \\
\text { AVE }\end{array}$ & $\begin{array}{l}\text { Lebih } \\
\text { besar } \\
\text { dari } \\
\text { nilai } \\
\text { korelasi } \\
\text { antar } \\
\text { peubah }\end{array}$ & $\begin{array}{l}\text { Semua } \\
\text { nilai akar } \\
\text { kuadrat } \\
\text { AVE dar } \\
\text { peubah } \\
\text { laten } \\
\text { lebih } \\
\text { besar dar } \\
\text { korelasi }\end{array}$ & Memenuhi \\
\hline
\end{tabular}

Sumber: Data diolah, 2019
Pada Model Akhir SEM PLS dapat diketahui dari Gambar 1 maupun tabel 1 bahwasanya peubah dari Kemampuan Keuangan (KK) yang dicerminkan dari tiga indikator yaitu kemampuan intelektual dari Ingatan (KK1), kemampuan intelektual dari kemahiran berhitung atau mencatat (KK2) dan kemampuan intelektual dari kecepatan konseptual (KK3). Hal ini pada peubah Kompetensi Keuangan dari 3 indikator tersebut terlaksana dengan optimal dan keseluruhan indikator tersebut indikator dari Kemampuan Intelektual dari berhitung atau mencatat segala transaksi mencerminkan nilai paling besar dengan nilai Loading Factor 0, 954.

Sedangkan Peubah Daya Saing dari 4 Indikator yaitu Quality, Delivery Dependability, Produk Innovation dan Time to market dan peubah laten dari keseluruhan indikator ini yang paling dominan memiliki nilai Loading Factor sebesar 0,886 pada Delivery Dependability dalam hal mengirimkan pesanan pelanggan tepat waktu.

Tabel 4. Hasil Penilaian Kriteria Inner

Model dan Standar Nilai Inner Model

\begin{tabular}{|c|c|c|c|c|}
\hline No & Kriteria & Standar & $\begin{array}{c}\text { Hasil } \\
\text { Penilai } \\
\text { an }\end{array}$ & Kesimpulan \\
\hline 1 & $\begin{array}{l}R^{2} \text { dari } \\
\text { peubah } \\
\text { laten } \\
\text { endogen }\end{array}$ & 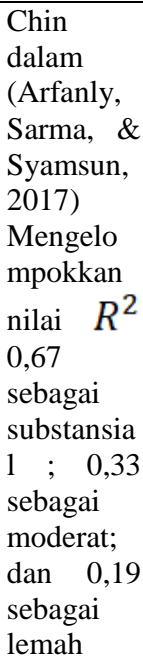 & $\begin{array}{l}R^{2} \\
\text { untuk } \\
\text { DY = } \\
0,080\end{array}$ & $R^{2}=$ Lemah \\
\hline
\end{tabular}




\begin{tabular}{|c|c|c|c|c|}
\hline No & Kriteria & Standar & $\begin{array}{c}\text { Hasil } \\
\text { Penilai } \\
\text { an }\end{array}$ & Kesimpulan \\
\hline 2 & $\begin{array}{l}\text { Estimasi } \\
\text { Koefisien } \\
\text { Jalur }\end{array}$ & $\begin{array}{l}\text { Pengaruh } \\
\text { nyata jika } \\
\text { t-statistik } \\
>\text { t-tabel. } \\
\text { Pada } \\
\text { alpha } 5 \% \\
\text { dengan } \\
\text { nilai t- } \\
\text { tabel } \\
\text { sebesar } \\
1,96\end{array}$ & $\begin{array}{l}\text { Nilai t- } \\
\text { statistik } \\
\text { KK } \\
\text { DY = } \\
1.608 \\
\text { Nilai } \\
\text { Koefisi } \\
\text { en } \\
\text { KK } \\
\text { DY = 0, } \\
108\end{array}$ & $\begin{array}{l}\text { - Kemampuan } \\
\text { intelektual } \\
\text { dalam } \\
\text { menyusun } \\
\text { laporan } \\
\text { keuangan } \\
\text { laporan } \\
\text { keuangan } \\
\text { tidak } \\
\text { berpengaruh } \\
\text { terhadap } \\
\text { Daya Saing }\end{array}$ \\
\hline
\end{tabular}

Sumber: Data diolah 2019

Model Struktural (Inner Model).

Setelah melakukan evaluasi pada peubah laten dari outer model maka langkah selanjutnya yang harus dilakukan yaitu mengevaluasi inner model yang merupakan analisis yang melihat hubungan antara peubah yang memiliki pengaruh positif atau negative. Dalam pengujian ini pada pengamatan R2 dari peubah laten endogen atau Daya Saing sebesar 0,080 . Hal ini menunjukkan bahwa peubah laten Daya Saing dapat dijelaskan oleh peubah kemampuan intelektual sebesar 8\% sedangkan 92\% dijelaskan peubah lainnya diluar yang diteliti.

Selanjutnya mengevaluasi dengan melihat nilai estimasi koefisien jalur yaitu pengaruh positif langsung dari konstruk laten dengan konstruk laten lainnya berdasarkan bootstrapping smartpls. Pada peubah Kemampuan Intelektual menyusun laporan keuangan tidak memiliki pengaruh nyata terhadap Daya Saing. Hal ini ditunjukkan dari nilai t-statistik yang lebih rendah dari pada t-tabel $(1.608<1.96)$. pengaruh yang tidak nyata tersebut dapat disebabkan dari kemampuan intelektual pelaku usaha dalam keuangan masih rendah terhadap daya saing dalam menjalankan usahanya.

\section{KESIMPULAN DAN SARAN}

Kesimpulan pada penelitian ini sebagai berikut:
a. Berdasarkan hasil dari analisis kemampuan intelektual menyusun

laporan Keuangan terhadap daya saing diketahui kemampuan intelektual menyusun laporan keuangan yang telah diimplementasikan oleh pelaku usaha masih lemah secara keseluruhan mencapai $8 \%$.

b. Berdasarkan analisis SEM PLS, ditemui bahwa peubah kemampuan intelektual menyusun laporan Keuangan tidak berpengaruh secara nyata terhadap daya saing

Saran pada penelitian ini yaitu: Pada Pelaku UMKM yang ada di Kota Batam perlu ditingkatkan kembali dalam kemampuan intelektual menyusun laporan keuangan bahwasanya dengan meningkatnya kemampuan tersebut para pelaku usaha yang ada di Kota Batam dapat unggul dalam hal persaingan terutama pada saat Era MEA.

\section{UCAPAN TERIMAKASIH}

Ucapan terima kasih saya sampaikan kepada Ristek Dikti dan Universitas Universal yang telah membantu atas semua hal selama proses penelitian.

\section{DAFTAR PUSTAKA}

Arfanly, B., Sarma, M., \& Syamsun, M. (2017). Peran Entrepreneurial Marketing dalam Peningkatan Kinerja Pemasaran pada Industri Rumahan Kabupaten Kendal, Jawa Tengah. MANAJEMEN IKM: Jurnal Manajemen Pengembangan Industri Kecil Menengah, 11(2), 141-150. https://doi.org/10.29244/mikm.11.2.1 41-150

Dhamayantie, E., \& Fauzan, R. (2017). Penguatan Karakteristik Dan Kompetensi Kewirausahaan Untuk Meningkatkan Kinerja Umkm. Jurnal Manajemen, Strategi Bisnis Dan Kewirausahaan, 11(1), 80-91.

Dwi, Kusuma, R., \& Rahardjo, Toto, S. (2017). Analisis Pengaruh Orientasi Kewirausahaan, Kompetensi Sdm, Inovasi, Dan Kapabilitas Sumber 
Daya Supplier Terhadap Keunggulan Bersaing Industri Logam Mesin Dan Elektronik Di Kabupaten Tegal. Diponegoro Journal Of Management, 6(4), 1-11.

Ghozali, I. (2008). Konsep dan Aplikasi dengan program AMOS 16.0.

Ghozali, I. (2015). Partial Least Squaeres Konsep Teknik dan Aplikasi Menggunakan Program SmartPLS 3.0. Semarang: Badan Penerbit Universitas Diponegoro.

Ghozali, I. (2016). Aplikasi Analisis Multivariete IBM SPSS 23 (8th Ed.). Semarang: Badan Penerbit Universitas Diponegoro.

Gursoy, D., \& Swanger, N. (2007). Performance-Enhancing Internal Strategic Factors And Competencies: Impacts On Financial Success. International Journal of Hospitality Management, 26, 213-227. https://doi.org/10.1016/j.ijhm.2006.0 1.004

Handriani, E. (2011). PENGARUH Faktor Internal Eksternal, Entrepreneurial Skill, Strategi Dan Kinerja Terhadap Daya Saing Ukm Di Kabupaten Semarang. Dinamika Sosial Ekonomi, 7(1), 47-69.

Hidayat, A., \& Suhayati, E. (2017). Pengaruh Kompetensi dan Independensi terhadap Kualitas Hasil Pemeriksaan Pajak. Jurnal Riset Akuntansi, IX(2), 26-36.

Martini, Tini ; Thamrin, Rammelsbergi, J. (2016). Kompetensi Usaha Mikro Kecil \& Menengah (Umkm) Kota Bandung Dalam Mengahadapi Persaingan Masyarakat Ekonomi Asean (Mea). Penelitian Pendidikan, 220-235.
Munizu, M., Surachman, Salim, U., \& Solimum.(2012). Pengaruh Praktik Total Quality Management (TQM) terhadap Budaya Kualitas, Daya Saing dan Kinerja Perusahaan (Studi pada Industri Manufaktur di Kota Makassar). Jurnal Aplikasi Manajemen, 10(3), 510-519.

Nurlaela, S. (2015). Kemampuan Menyusun Laporan Keuangan UMKM Pengaruhnya terhadap Kinerja UMKM Kerajinan Gitar di Kabupaten Sukoharjo. Paradigma, 12(02), 50-59.

Putut, A. (2019). Ekonomi Batam Melambat pada 2019; Prediksi. Retrieved from Batam Pos website: https://batampos.co.id/2019/01/21/ek onomi-batam-melambat-pada-2019prediksi/

Singgih, S. (2011). Structural Equation Modeling (SEM) Konsep dan Aplikasi dengan Amos 18 (Edisi 1). Jakarta: PT Elex Media Komputindo.

Singgih, S. (2017). Menguasai Statistik dengan SPSS 24. Jakarta: PT Elex Media Komputindo.

Sugiyono. (2017). Metode Penelitian Kuantitatif Kualitatif dan $R \& D$. Bandung: Alfabeta.

Undang-Undang No. 20. (2008). Tentang: Usaha,Mikro,Kecil dan Menengah. Sekretariat Negara. Jakarta.

Zulgani, Syaparuddin, \& Parmadi. (2014). Analisis Daya Saing Produk Agroindustri Subsektor Perkebunan dalam Perekonomian Wilayah Provinsi Jambi. Jurnal Perspektif Pembiayaan Dan Pembangunan Daerah, 2(1), 29-38. 